NB: This paper is a pre-publication version that appears in lieu of the publisher's own version of record.

\title{
(Dis)located Olympic patriots: Sporting connections, administrative communications and imperial ether in interwar New Zealand
}

\author{
Geoffery Z. Kohe \\ University of Worcester
}

\begin{abstract}
During the interwar period (1919-1939) protagonists of the early New Zealand Olympic Committee [NZOC] worked to renegotiate and improve the country's international sporting participation and involvement in the International Olympic Committee [IOC]. To this end, NZOC effectively used its locally based administrators and well-placed expatriates in Britain to variously assert the organisation's nascent autonomy, independence and political power, progress Antipodean athlete's causes, and, counter any potential doubt about the nation's peripheral position in imperial sporting dialogues. Adding to the corpus of scholarship on New Zealand's ties and tribulations with imperial Britain (in and beyond sport) (e.g. Beilharz and Cox 2007; Belich 2001, 2007; Coombes 2006; MacLean 2010; Phillips 1984, 1987; Ryan 2004, 2005, 2007), in this paper I examine how the political actions and strategic location of three key NZOC agents (specifically, administrator Harry Amos and expatriates Arthur Porritt and Jack Lovelock) worked in their own particular ways to assert the position of the organisation within the global Olympic fraternity. I argue that the efforts of Amos, Porritt and Lovelock also concomitantly served to remind Commonwealth sporting colleagues (namely Britain and Australia) that New Zealand could not be characterised as, or relegated to being, a distal, subdued, or subservient colonial sporting partner. Subsequently I contend that NZOC’s development during the interwar period, and particularly the utility of expatriate agents, can be contextualised against historiographical shifts that encourage us to rethink, reimagine, and rework narratives of empire, colonisation, national identity, commonwealth and belonging.
\end{abstract}




\section{Key words}

Commonwealth, New Zealand Olympic Committee, Olympic history, inter-war period, historical agents

\section{Introduction}

As a former colony and Dominion of the British Empire and, at present, a Realm of the Commonwealth, New Zealand has continued a historically nuanced, politically significant, economically valuable and ideological laden relationship with its imperial coloniser (Belich 2000, 2009; Coombes 2006; Pickles 2009; 2011; Sinclair 1986; Palenski 2012; Ryan 2004, 2005). In this paper I discuss significant aspects of this history with reference to New Zealand's national Olympic committee and its nascent presence in the developing international Olympic movement (Henniker \& Jobling 1989; Jobling 2000; Kohe 2010, 2011; Little \& Cashman 2001; Letters \& Jobling 1996). ${ }^{1}$ I focus predominantly on the interwar period (demarcated by the New Zealand Olympic Committee’s [NZOC] official recognition by the International Olympic Committee [IOC] in 1919, and, administrative changes wrought by the onset of British Empire Games in the 1930s) as a context to examine and articulate some of the complexities and characteristics of New Zealand's imperial associations, identities and loyalties, and transnational connections. ${ }^{2}$ During this time NZOC's early participation in the international sporting scene was, to an extent, largely contingent not primarily on British agents, but instead, a few successful and well-placed expatriate New Zealanders in Britain (namely Arthur Porritt and Jack Lovelock) who worked closely with NZOC members (particularly, Secretary-General Harry Amos) to provide a voice for New Zealand sporting concerns, and, a useful conduit for transmitting information to and from Britain and the IOC. ${ }^{3}$ Below I detail how such expatriate agents worked with NZOC administrators to help fortify the organisation, advocate for its causes within Britain, Europe and the IOC, facilitate the country's athletic competition abroad, and, better enable administrators to respond to athletes' 'professional' needs. In so doing, I raise questions regarding the strength and political influence of the imperial core in determining (and controlling) New Zealand’s peripheral sporting participation.

New Zealand's colourful and proud Olympic history aside (see Palenski \& Maddaford 1983; Palenski \& Romanos 2000; Romanos 2006 for examples), I argue in this paper that an examination of NZOC during the interwar period reveals much about the nation's fragmented 
relationship with Britain (at least in the contexts of amateur athletics and the Olympic movement). By examining Amos, Porritt and Lovelock, in particular, I suggest that New Zealand's Olympic ties during this period were rarely demonstrative of a linear power hierarchy (in which direct authority is transcribed from the core to the periphery). Rather, the formative years of NZOC's relationship with Britain and its international sporting partners could be characterised as fairly fragile; mediated precariously via a set of strategically located, socially mobile and diplomatically adept, agents. As I detail below, expatriates such as Porritt and Lovelock, and the communications they maintained with administrators in the Antipodes, not only positively affected New Zealand's athletic participation in the Olympic movement and abroad, but also, provided the country with valuable representation in international sporting circles. In addition to political advocacy, these agents helped secure New Zealand's on-going representation and participation in the IOC, and, eventually led to a long-serving membership status that continues to be highly valued by NZOC and acknowledged as an important part of its Olympic history (Kohe 2011, 2012).

Drawing on the work of scholars such as Beilharz and Cox (2007), Belich (2001, 2007), Coombes (2006), Mangan and Hickey (2000), Phillips (1984, 1987, 1990), Ryan (2004, 2005, 2007) and others - who all in their various ways encourage critique of imperialism, (sporting) nationalism and identity, empire, and, colonial power and its consequences -, this paper examines one facet of New Zealand's early sporting relationship with Britain. The paper takes as its focus the context, and political interactions therein, of transnational Olympic administration, and, specifically, the actions of key agents within the initial decades of NZOC's formation. My argument is two-fold. First, I contend that the antecedents, and formative involvement, of New Zealand's participation in the Olympic movement resides in a close but invariably fragile and inconsistent set of relationships and communications between key administrative agents; namely expatriates Arthur Porritt and Jack Lovelock, and, their resident countryman, Harry Amos. Secondly, I argue that by their geographical location and mobility, political representation, social status and athletic nous, New Zealand agents (at least in the case of Porritt and Lovelock) could not be considered peripheral participants in global athletics, the activities of the Olympic movement, or, the genesis and consolidation of a Commonwealth sporting fraternity. To appreciate the colonial contours and imperial intricacies of this period, I begin with a short articulation of the periodic milieu. 


\section{Fortification forces, NZOC and Olympic sport}

Not unlike other sport bodies within the country, and within other parts of the British Empire, NZOC emerged at an historical juncture punctuated globally by imperial rhetoric, international political manoeuvrings, nascent nationalistic sentiment among the colonies, and developing transnational rivalries in and beyond sport. The evolution of the national committee was also contoured domestically by social and political reform, growing economic productivity, radical state liberalisation, vigorous civic development, and population expansion (Belich 2001; King 2003; Palenski 2012; Ryan 2004, 2005, 2007; Sinclair 1984, 1986; and Sinclair and Dalziel 2000). Throughout the interwar period, these, and other, modernising conditions - overviewed below - variously contoured New Zealand relationships with Britain, the development of its imperial and individual identities, its formative (yet fluid) conceptualisation of nationhood, the structure and ethos of its sporting (and particularly amateur athletic) culture, ${ }^{4}$ and, the subsequent setting in which agents in the young NZOC went about their work. The period was a definitive time for NZOC, not only in terms of athletic successes it was able to facilitate, but also for fortifying its administrative structures, maintaining its economic viability, consolidating its social and cultural importance, and, securing its legitimacy as one of the country's premier sporting authorities.

In the first instance, the cancellation of the 1916 Olympic Games (scheduled for Berlin) due to World War One did not totally curtail NZOC members' activities or related sporting events for that matter, or, their communications with imperial allies; namely, Australia and Britain. Rather, the event enabled NZOC to assess its national significance, and, demonstrate its support for the collective war-time cause. A consequence of NZOC maintaining and proclaiming its associations with the Empire, and capitalising on the (inter)nationalistic camaraderie embedded in war-time ethos, was that it could effectively engender public support for its institution and entrench its role as a key sporting agency. "It is most pleasing”, then Secretary General Arthur Marryatt noted, "that some many athletes had volunteered for the front...", however, the War had unfortunately "robbed (amateur sport) of a good deal of its visual interest". ${ }^{5}$ Marryatt's NZOC colleagues appeared to share his sentiments. "It is a matter of extreme gratification to the Council”, one delegate proclaimed, "that in the great conflict in which our Empire is at present engaged, so many amateur athletes are at present of active service”. ${ }^{6}$ Sport was appropriate preparation for their defence of the Commonwealth, the delegate continued, and, 
"although their absence will be felt during the coming season, the Council knows that the training they received [through sport] will stand them in good stead for their arduous duties, and will prove of the greatest assistance in the share of our forces in the maintenance of British prestige. The absence of our fellow athletes on the King's service should make us the more diligent in keeping the sport at its usual high level...[also]...sports meetings..., wherever possible, should be devoted to entirely Patriotic purposes". 7

Similar sentiments were echoed by other NZOC members, and, formed part of a wider ideological marriage between sport and militarism that permeated other sport organisations in New Zealand and further abroad (Richardson \& Richardson 2005). ${ }^{8}$

War exacerbated international and political forces and had a resounding influence on the maintenance of New Zealand's relationship with Britain as well as its developing identity as part of a sporting commonwealth. Even though the war consumed a large contingent of New Zealand's male population, it did not result in the cessation of sporting activities in the country, but rather, imbued the competitions and events that did continue (including those within amateur athletics) with strong jingoistic fervour, international camaraderie and militaristic sentiment. ${ }^{9}$ Although NZOC convened irregularly during the War, agents such as Marryatt worked hard to ensure the New Zealand maintained a presence at the next international sporting table in close proximity to its wartime partners. Consequently, NZOC emerged after World War One, well-poised to manage the country's athletic scene and facilitate international sporting competition and, by 1919, was effectively positioned to lobby the IOC for its separate recognition. ${ }^{10}$

Notwithstanding its significance, war was just one defining force of the times. Economic and social reforms, brought about by then Prime Minister William Massey's conservative government, attempted to stimulate post-war productivity and appeal to developing allusion of class mobility (Belich 2001; Roche 2002). Although new-found economic and social mobility may have been enjoyed by some, by and large (and especially in sport and the context of amateur athletics), class exclusions, limitations, and ideological constraints prevailed. ${ }^{11}$ Echoing the composition of their contemporary sport organisations in Britain and the Australia, control of NZOC notably still resided with an elite group of educated, white, middle-class agents. For NZOC's effective management and success this was no great issue; in fact, as will be explored below, the social status of members and associates such as Arthur Porritt and Jack Lovelock was ultimately a useful mechanism in their participation in the elite echelons of British, European and IOC sporting circles. 
Subsequent to the effects of the war and the economic changes experienced during the 1920s, NZOC’s imperial relationship (and international sporting participation) was also shaped by the onset of the Great Depression (c.1929-early 1930s). The effects of the global economic collapse did not, Grant $(1997,138)$ remarks, immediately affect New Zealand's economy, and, stock brokers appeared "blithely indifferent" to the catastrophe. The inevitable outcomes of downturns in trade and consumption, rises in unemployment, social unease, and health and welfare issues eventually came; however, the effects were varied (Belich 2009; Molloy 2007; Olssen, 1995). ${ }^{12}$ In sport, organisations such as NZOC, which since formation continued to be in a fiscally precarious position, appeared initially unscathed. NZOC persevered throughout the early 1930s in balancing their books and protecting and preserving its small economic resources. ${ }^{13}$ In 1931, however, NZOC Chairman Harry Amos wrote to the IOC outlining the financial and practical constraints the committee faced in sending a team to compete in the upcoming 1932 Los Angeles Olympic Games. ${ }^{14}$ In 1934 Amos wrote again, this time directly to the IOC President Henri Baillet-Latour, lamenting about the hardships of the Depression and life in New Zealand. ${ }^{15}$ In particular, Amos stressed the necessity for both organisations to do what they could to ensure to future of Olympic sport.

The Depression, along with the onset of the country's first Labour government which took power in 1935 and promised considerable social, industrial and political reform, did however precipitate a discernible contextual shift in New Zealand and beyond in its ties with Britain. While it is difficult to confirm the extent to which the Depression definitively influenced NZOC's relationship with Britain, its presence as an agenda item in correspondence between agents in New Zealand and their counterparts in Britain suggests that it was a valuable cause around which they could rally collective empathy and support. Although distinct from the atrocities of War, the Depression was similarly global in its reach and consequence, and, likewise involved international political and economic intricacies that were manipulated to varying degrees by enduring and contemporary imperial forces and ties. For NZOC specifically, this necessitated maintaining effective working relationships with their established imperial friends and ensuring they had appropriately placed and capable spokesmen (e.g. Harry Amos) to advocate for New Zealand concerns in the global sporting marketplace.

\section{Amos the Antipodean advocate}


Against this post-war backdrop of mixed parts global redirection and uncertainty and national efforts to improve productivity and instigate social change (Keys 2006; Krüger \& Murray 2003), NZOC agents worked to better their organisation. One of the foremost agents in this project was Harry Amos. While not the first head of NZOC, he was active as Chairman of the organisation from 1928 until 1934 and then continued in the capacity of Secretary General from 1934 until 1950 (eventually becoming one of the organisation's longest serving leaders). Where previous administrators, such as Arthur Marryatt, Arthur Davies, and Charles Camp had been preoccupied with NZOC's domestic profile, Amos actively went further to improve the tyrannies that geographical distance wrought. ${ }^{16}$ Amos was arguably the most dedicated in developing a closer and more direct relationship with the IOC. At a time when the vestiges of World War One still lingered and international insecurities begat increasingly politicised sporting nationalisms (Keys 2006; Krüger \& Murray 2003), Amos was evidently, and importantly, outward looking.

Yet, in the mid-1920s Amos did not necessarily inherit an organisation that was well equipped to ensure its financial survival, and with this, continue to grow the country's now historically noteworthy and nationally recognised participation in international athletic sport. Having long been involved in the country's amateur athletic scene (first as a cyclist, then as an administrator), Amos had witnessed the rapid development and modernisation of the national and international sporting landscape and benefited from watching successive leaders struggle with the difficulties of NZOC's inception and survival during its early years. Over the course of his tenure Amos subsequently enacted a series of changes that improved NZOC's fiscal resilience and enabled the committee to maintain its international and imperial allegiance and memberships. ${ }^{17}$ Foremost in his actions were the decisions to seek better IOC representation. Although Arthur Marryatt had acted somewhat effectively as IOC member between 1919 and 1923, subsequent appointments had been disappointingly ineffective. ${ }^{18}$ Amos' frustration was fairly clear. "I really believe", Amos wrote to IOC member Bernard Freyberg, "that it is necessary for you to consider if it would not be advisable to send in your resignation and make place for a man who could take better care of the interest of the Dominion”. ${ }^{19}$ In his reply Freyberg lamented that distance and military commitments had prevented him from fulfilling his IOC and NZOC obligations. "I am very sorry", Amos appears to reply in empathy, "that you will be very likely never be able to give more time to our Committee and there that you have considered yourself bound to send in your resignation as member of the IOC for New Zealand". ${ }^{20}$ Through trial and error, Amos evidently appears 
to have realised the need for enthusiastic, communicative, proactive associates (preferably located abroad) capable of advocating on behalf of one of the country's premier sporting authorities.

Further evidence of Amos’ leadership came when he also acted as manager, and chaperone (alongside his wife), to the 1928 Olympic Games in Amsterdam. In so doing he was the first NZOC administrator to accompany the team abroad. ${ }^{21}$ As manager Amos experienced first-hand the difficulties New Zealand athletes and their support crews faced in competing successfully in international sport. New Zealand's commitment to the Olympic 'movement' (at that point ambiguously characterised and defined largely by its internationalisation and growing athletic participation) required, Amos acknowledged, dedicated domestic economic efforts that could “...remove from the shoulder of the Council the very arduous task of collecting money to dispatch a team". ${ }^{22}$ The effects were not necessarily immediate, and Olympic teams remained relatively small for some time. Although the athletes "did not meet with the success anticipated", Amos felt that the committee had been placed on a solid foundation. ${ }^{23}$

Amos' evident intentions were to improve NZOC's ability to meet athletes' needs and their international, transnational, and eventually Commonwealth, sporting expectations and obligations are commendable. Amos' strategies included more vigorous fundraising campaigns, establishing a dedicated and reliable network of domestic sponsors, donors and patrons, soliciting mainstream press outlets to raise the NZOC's public profile, instigating a more widespread, and regular, subscription scheme, lobbying for more consistent government support, and, ensuring the organisation was kept abreast of Olympic (and Empire) Games plans well in advance. ${ }^{24}$ Yet, the committee's success, at least for Amos, was contingent on establishing more permanent, and reliable agents abroad who would be cognizant of adversities faced by the country's elite athletes and be socially and politically well-placed to contribute to New Zealand's Olympic profile. ${ }^{25}$

\section{Exercising expatriates}

To this end two expatriates, Arthur Porritt and Jack Lovelock (each successful athletes, scholars and medical professionals) were fortuitously placed (Colquhoun 2008; McNeish 1986, 1999; Romanos 2006, 2008). Both men were seminal figures in the nation's popular 
sporting imaginary and retained prestige as beloved New Zealand citizens abroad. Porritt and Lovelock also both effectively capitalised on their athletic and academic prowess to establish prominence in European sporting circles, elite British higher education systems, and, their respective medical professions. By virtue of their sporting knowledge, social capital, national affectations, and residence in Britain, these men proved invaluable assets to NZOC. Their early (and in Porritt's case rather enduring) pas de deux with NZOC fixed in place a more resolute and reliable link between New Zealand and the global athletics and Olympic sporting community. More so than this, their respective, intertwined, and nuanced involvements in the domestic and international Olympic organisations provide reason to argue more strongly for the role New Zealand agents actively played (and British agents did not) in disrupting core and periphery power hierarchies (vis-á-vis sport) in the post-colonising context. Porritt's and Lovelock's relationships with the national committee provide some evidence to reconsider NZOC not as a compliant, distant, partner in the linear development and burgeoning growth of Olympic (or British Empire) global sporting projects, but as an organisation acutely aware of its changing international identity and capabilities to drive its own destiny. I discuss each of these men now in turn, and, then consider their wider utilities within reconceptualising New Zealand's relation with the Empire or more specifically NZOC's associations with Britain and the Olympic movement.

\section{Porritt, political patronage and (ex)patriotic performances}

Arthur Porritt's life has been extensively documented elsewhere (Woodfield \& Romanos 2008). However, to rehearse some of the key details: Born in 1900, Porritt's entrance into sporting administration was preceded by a solid educational background first as a boarder at the prestigious Wanganui Collegiate, and later, as medical student at the University of Otago, and vigorous sporting participation at college, national and eventually international level. Porritt's university success in New Zealand led to the award of a Rhodes scholarship to Oxford; which he took up at Magdalen College in $1924 .{ }^{26}$ While studying medicine, Porritt actively contributed to the sporting life of Oxford's student community (Woodfield \& Romanos 2008). Whether by athletic talent, previous national recognition in New Zealand, social connections with sport administrators back home, or, geographical position (possibly a combination of all four), Porritt earned nomination to compete at the 1924 Olympic Games in Paris as a member of the New Zealand team. At just 24 not only was Porritt nominated as an 
athlete, but, he also assumed responsibility to captain and manage the team. ${ }^{27}$ Porritt's athletic apex was his bronze medal in the 100 metre sprint at the 1924 Paris Olympic Games (Kebric 2014).

Beyond his sporting success Porritt was also highly regarded. As Amos remarked when nominating Porritt for IOC membership in 1934, "Dr Porritt is a New Zealander and is a Rhodes Scholar, he has been a good all round athlete, and is imbued with the highest ideals of sportsmanship”. ${ }^{28}$ Olympic success notwithstanding, as a collegial and affable expatriate with a newfound, yet strategically useful, knowledge of the United Kingdom's amateur athletic community, Porritt was suitably placed to assist NZOC and aid its communication with the imperial centre. In his managerial/captaincy role, for example, he helped source training facilities, accommodation and transport prior to the New Zealand team's arrival in Britain; offered NZOC financial contributions to assist their operations; provided medical expertise and training advice; and, even before he was made and IOC member in 1934, was active in expressing NZOC views and New Zealand concerns at Olympic congresses (Colquhoun 2008; NZOC 1912-1932; Woodfield \& Romanos 2008). Between 1922 and 1934 Porritt worked with NZOC improving not only the country's Olympic and eventual Empire Games sporting successes, but also, provided a more effective and reliable conduit of information from Europe to New Zealand administrators. NZOC, in return, clearly appreciated not only the work Porritt did for the committee and its constituents while enjoying having a competent and successful 'national' citizen on whom they could rely.

NZOC (or at least Amos as its Chairman) understood that a man of Porritt's virtue and social calibre reflected positively on its organisation and its international image in IOC, British and European sporting circles. Amos' nomination was a sensible choice. Porritt served as IOC member for New Zealand for 34 years. For 16 of those years he chaired the British Empire and Commonwealth Games Federation, and, was President of the IOC's inaugural Medical Commission. Retiring from the IOC role in 1966, Porritt returned to New Zealand for a 5 year stint as Governor-General, after which he migrated back to England where he resided until his death in 1994 (Woodfield \& Romanos 2008). Porritt's position in England, his lengthy service on the IOC, his professional medical and athletic knowledge, social capital and personal passion he evidently demonstrated in conducting sporting administrative affairs on New Zealand's behalf endeared him to his NZOC peers. 
The imperial relationship also went the other way. Porritt's formative years spent in New Zealand and his interest in NZOC and the country's sporting community, were evidently aspects to his life he valued. Porritt may have been, as Woodfield and Romanos (2008, 296) suggest, “a remarkable man, cushioned by success in every direction”; however, he saw merit in maintaining involvement in New Zealand affairs. Yet, Porritt might be considered a peculiar agent. Residing for the majority of his life in England, and by not being an official NZOC member, it would be easy to relegate Porritt to the margins of New Zealand's early history in the Olympic movement. Yet, by analysing Porritt's sustained interest in his 'home' country it is possible to understand that while NZOC evidently benefitted from having someone of Porritt's ability to effect political participation at a global and imperial level, concomitantly the organisation gave Porritt a clear link back to the Antipodes. In addition, with its emphasis on premier sporting achievement, NZOC also provided a distinct patriotic and nationalistic cause which Porritt could identify with. The IOC membership also afforded opportunities to fraternise with the upper echelons of the global sporting community and enjoy the convivial camaraderie of his Commonwealth companions (Woodfield \& Romanos 2008).

Porritt was, however, just one mechanism in a set of broader transnational processes and networks of people and information that produced, reproduced, and disrupted imperial relations. Taking cues from Pickles and Thompson \& Federowich - who urge us to destabilise and problematize notions of the 'core' and 'periphery' dichotomy in imperial debates (For example, Belich [2001, 2009]; Gibbons [2003]; Phillips [1989]; Pickles [2009, 2011]; Thompson \& Federowich [2013]) ${ }^{29}$ - it is possible to see Porritt anew. Echoing Pickles' (2011) sentiments about reconfiguring parochial intentions embedded within colonial histories, Porritt should be conceived of as more than just an individual New Zealand agent operating abroad. His contributions were not simply about advancing the Olympic movement within New Zealand per se but also to support and fortify New Zealand's nascent postcolonial identity, imperial allegiances, and place in the Olympic movement through representation and participation at the highest levels of international sport. Porritt's emergent quasi-cosmopolitan identity, personal affections for the antipodes and colleagues therein, participation in global sport politics, and expatriate desire to sustain connections to 'home', for instance, effectively highlight some of the ways in which NZOC's early development and Britain's bond with its colonies and Dominions is potentially more nuanced, complex, and nationally transcendent than might be imagined. 


\section{Lovelock links}

Porritt was not, however, the only active agent abroad. One of his contemporaries, and friends, Jack Lovelock was also instrumental in developing the national organisation's transnational relationships, profile and successes and related imperial connections. Albeit 10 years Porritt's junior, Lovelock was comparably invested in New Zealand sport and helping NZOC improve its practices to ensure future international success. Like Porritt, Lovelock's life has drawn significant attention elsewhere (Colquhoun 2008; McNeish 1986, 1999; Romanos 2006, 2008; \& Woodfield 2007). From an early age Lovelock demonstrated a highlevel of sporting and educational prowess. His studies took him to the University of Otago, Dunedin, where he studied medicine and ran competitively at the national amateur athletic level. In 1931 he was awarded a Rhodes scholarship to Oxford which he took up at Exeter College. While at Oxford Lovelock was quickly introduced to the British and international amateur athletic scene. His successes and records over the 1mile and 1500 metre distances gained him recognition and subsequent selection for the 1932 Olympic Games in Los Angeles, the 1934 British Empire Games in London and the 1936 Olympic Games in Berlin. At the Berlin Olympic Games reached his athletic peak, winning gold in the 1500metre event (Colquhoun 2008; Woodfield 2007). The event, unsurprisingly, endeared him to New Zealand fans back home. ${ }^{30}$

Lovelock’s win in 1936 was particularly profound. "Lovelock did more than win an Olympic title", one media correspondent remarked, "he won the admiration of the sporting world for his attitude to sport”. ${ }^{31}$ For administrators back in New Zealand, Lovelock's victory could not be ignored. NZOC quickly went to work to lobby the government for funds to support Lovelock's tour of New Zealand. Their efforts were significantly enhanced by the fact the one of their members, Joseph Heenan, was Secretary of the Department of Internal Affairs. "If this were a simply a matter of giving an athlete a free trip I would unhesitatingly recommend against it”, Heenan remarked, "but, Lovelock is more than merely the greatest mile runner the world has yet produced. I feel sure he is of great physical and education value, for Lovelock has made a really scientific study of sport” (Woodfield 2007, 94). The New Zealand Government responded positively. Over the southern hemisphere summer of 1936/1937 Lovelock was provided with passage 'home' and treated to lavish hospitality around the country that included banquets, state occasions, gifts and public accolades (NZOC, 1933-1934; Woodfield 2007). In addition to competing in several invitational and exhibition running events, Lovelock toured the country offering his athletic and medical 
expertise to fellow athletes and scientists and educationalists. "2. "Large, enthusiastic crowds", Woodfield (2007, 97) notes, “welcomed him where ever he went”. Reflecting on Lovelock's visit after his departure, Ingram noted fondly, "he gave we New Zealanders much good advice” (sic). ${ }^{33}$ Following the tour Lovelock returned to England. He later served in the Royal Army Medical Corp during World War Two, and, shortly thereafter moved to New York where he continued to practice medicine up until his untimely death in 1949 (Colquhoun 2008; Woodfield 2007).

In understanding the utility of these men within the imperial sporting context it is difficult to deny their specific corporeal politics. Lovelock and Porritt were not only reflections of NZOC's proficiency as a competent national sporting body, though also, were physical embodiments of colonial dominance. Both men, for example, were archetypes of a hegemonic conceptualisation of a fairly nascent 'New Zealand' identity in that they simultaneously epitomised the 'success' of empire, the vitality of the nation, and, the masculine (yet gentlemanly) vigour of its sporting culture (Phillips 1989; Palenski 2012). Despite the country's political autonomy and some of the emergent iconographical markers of identity (e.g. flag, anthem, silver fern, black singlet etc...) that had emerged prior to and during World War One, ${ }^{34}$ distinctions about who New Zealanders were and who they were not mattered. Against the interwar and post-Depression backdrop, Lovelock's success and subsequent visit clearly offered the nation a visible conduit through which to channel shared sentiments about (a domineering white, athletic, pioneering, forthright, collective version of) 'New Zealand’ identity (Belich 2001, 2009; King, 2003; Phillips 1984, 1987; Sinclair, 1986; Sinclair \& Dalziel 2000).

Given the fact that Lovelock had been living abroad since 1931 and only ever returned for this one visit, the veneration he received as 'national' figure and sporting patriot might certainly be considered perplexing. Yet, evident in the public attention he was given, the hospitality he was afforded and commentary he drew in popular press was the idea that here was not just a world-class athlete, but also, a world-class New Zealander; a man who, in his athletic prowess and gentile-manner, exhibited simultaneously the best of nation's 'homegrown' talent, but concurrently embodied, a fine, polished-abroad, specimen of the imperial stock. Lovelock was, as Amos remarked to his NZOC colleague, “a very distinguished son” of whom the country and organisation could be rightly proud. ${ }^{35}$ Lovelock, in response, played his part by maintaining fairly regular, detailed, and scientifically progressive communications with administrators in New Zealand, fulfilling informal ambassadorial roles in supporting 
New Zealand athletes abroad, and, notably, by offering NZOC an on-going critical friendship from afar. ${ }^{36}$

\section{Colonial contemplations and the 'cultural cringe'}

The examination of a few key figures in the early history of the Olympic movement in New Zealand is useful in articulating some of the ways in which the country negotiated its participation in international sport and imperial identities and allegiances during the interwar period. While this might be important sport history, such a study assumes an additional salience when contextualised against disciplinary shifts in imperial and national historiography that have occurred within and beyond New Zealand's shores. Some of the changes have been alluded to at the outset of this paper (recall Pickles 2009, 2011), yet they are worth detailing further. For the last 40-odd years New Zealand historians, and those elsewhere, have strongly contested the post-colonial(-esque) paradigm alteration in imperial scholarship (e.g. Fairburn 1989; Munz, 1971, 1984; Fergusson 2008). ${ }^{37}$ Disciplinary movement has been heralded (and welcomed), by other historians, in the hope that it might provide a counterpoint to, and a displacement and disruption of, dominant nationalistic narratives (e.g. Belich 2009; Burton 2003; Gibbons 2003; Lambert \& Lester, 2006; Pocock, 1974; Thompson \& Federowich 2013). Essentially, the intention is to take us from, what Pickles (2011, 87) laments as "the spotlight on British settlers and their colonial legacy", toward new modes of transnationally intricate inquiry that might remap and remake current ideas about geopolitical and ideological allegiance and identity. A key tenet of this debated scholarly shift is the rejection of narratives over-emphasising the role of the Empire (in this case the British version thereof) within processes and consequences of colonisation and, subsequent, postcolonial identity formation and belonging (Beilharz \& Cox 2007; Pickles, 2009, 2011). Explicit within this rejection, Pickles argues, is the related need to debunk, and transcend, the 'cultural cringe' aspect inherent within nation-based colonial history projects; characterised namely by excessive and needless comparisons with Britain/British schools of thought, parochial constructions of historical agency centred on an imperial core, and, misplaced assumptions about inferiority and power relations. ${ }^{38}$

Bearing in mind the arguments above, the crux of this paper is, essentially, that New Zealand agents were not passive participants in the country's imperial and transnational relations during the interwar years. Rather, connections forged first by people like Amos, and 
then more directly by expatriates such as Porritt and Lovelock, were instrumental in establishing New Zealand sport administrators as active contributors to global athletic sport. Taking account of Pickles’ comments, Amos, Porritt and Lovelock were not merely reactive agents responding to circumstances that lay beyond their immediate control or influence. Nor, for that matter, did they accept their political membership being mediated through British counterparts. Their most significant contributions - certainly in the framework of contemporary trends in imperial historiography, to which this special edition contributes were the parts each played in reaffirming New Zealand's nascent sporting identity, and, contesting a sense of the country's peripheral, and by default subordinate, status within international sporting fraternities. Through their achievements, roles, status and administrative prowess, figures such as Amos, Porritt and Lovelock (along with other contemporaries in other key sporting institutions) contributed to the vitality of New Zealand's sporting culture and the professionalism of its Olympic administration. Concomitantly, however, as 'expats' the latter two men were also emblematic of the 'success' of sporting and educational colonialism, and as such, were positive reflections (and ambassadors) for Britain and the empire. Although Porritt and Lovelock's were valuable to NZOC and its imperial relationships, I argue here that their utility needs to be situated within critical historiographical assessments that explore the country's increasingly stronger national sentiment, sense of collective national purpose and political quest for greater autonomy, and respect for the historical significance of imperial membership (e.g. Palenski 2012; Byrnes 2009; MacLean 2010). ${ }^{39}$

Operating largely from abroad, these men (I recognise that there were others with whom they worked) effected change in the ways NZOC went about its work; namely by providing an information channel and more resounding voice for New Zealand sporting concerns at an international level. Amos, Porritt and Lovelock's agency provides reason to query New Zealand's peripheral place within conceptions of Empire and discussions about imperial allegiance. Porritt and Lovelock, in particular, demonstrated that New Zealand (or more precisely NZOC) did not have to be reliant on their British counterparts to mediate their participation on the world stage. For Amos the historic imperial links with Britain, though not inherently problematic, begat frustrating pragmatic concerns (e.g., impeded information flows, ideological challenges over the specificities and peculiarities of amateurism and the inability to implement effective-long term financial planning) that curtailed New Zealand's Olympic participation (and eventual success). Amos' approach to the internationalisation of 
NZOC (at least in terms of Olympic participation) is partial evidence of an attempt to redefine the historic power relations (and imbedded administrative subservience therein) within colonial and imperial sporting ties. Although part of the reliance on Australia and Britain had been borne out of historic, pragmatic and/or economic necessities, during this interwar period, NZOC used its own members, and their political acumen, to announce and consolidate their independence, autonomy and identity. Affiliations with the Empire may have mattered to a degree, ${ }^{40}$ yet such associations were effectively secondary to the desire for NZOC to be truly and fully an active constituent of transnational sporting affairs.

The arguments about imperial connections rehearsed in this particular paper only go part of the way toward this changing our disciplinary visions of imperial relations. I also recognise my interpretations here are limited. I have, for instance, only focused on a few key agents at one specific historical moment. Moreover, there is still much we do not know about the articulation of empire within particular sporting contexts during this period. Nonetheless, by foregrounding some of the distinct roles particular New Zealanders played in determining NZOC's international and imperial sport participation it is possible to appreciate some of the ways in which the country was negotiating its relationship with Britain at a key historical juncture. Amos, for example, took a lead role in ensuring NZOC's retained a visible presence in the Olympic Games and that its role in the movement writ large could be assured irrespective and independent of its imperial relationships. To recall Pickles contentions here about rethinking core/peripheral dynamics (Pickles 2011), the ways in which Amos operated and undertook affairs on behalf of NZOC was not, it need be said, an attempt to wrestle more authority, control or autonomy from the core to the periphery. Rather, here was an example of an outlying (though historically noteworthy) member of the Empire strategically seeking opportunities to better communicate with the global sporting fraternity. ${ }^{41}$

Colleagues such as Porritt and Lovelock worked in their own particular ways to help Amos achieve some of these goals. To their credit, and notwithstanding the influence of structural forces and/or individual protagonists, all three men worked to challenge and change the country's sporting profile and its political participation abroad and punctuate imperial athletic conversations with a distinct Kiwi twang. Where Lovelock aided NZOC's public profile in the short term, Porritt exhibited a more enduring commitment to the organisation. The efforts of England-based expatriates such as Porritt and Lovelock, too, help reveal that New Zealand's evolution in the Olympic movement was not just mediated from afar but was contingent on strategically (dis-) located, white, educated, upper-middle class agents who 
were best placed to affect and advocate for its causes. Such was their influence and success that they helped set NZOC on a trajectory where they would no longer be considered a peripheral participant in global athletics or the activities of the Olympic movement, but rather, a key member of an international sporting fraternity.

\section{Endnotes}

${ }^{1}$ New Zealand's associations with the Olympic movement tentatively began in 1892 when there was a brief, and much mythologised, interaction in Paris between leading New Zealand amateur athletics administrator Leonard Cuff and eventual renovator of the modern Olympic movement Baron Pierre de Coubertin. An eventual consequence of this meeting was Cuff's co-option onto the inaugural International Olympic Committee (IOC). Yet, the co-option did not give immediate rise to the New Zealand Olympic Committee (NZOC). See, variously, Henniker and Jobling, 'Richard Coombes and the Olympic Movement in Australia'; Jobling, 'In pursuit of status, respectability and idealism'; Kohe, 'The unexceptional'; At the heart of sport; Little and Cashman, 'Ambiguous and overlapping identities'; and, Letters and Jobling, 'Forgotten links'. To note also, the Committee originally began as the Olympic Council of New Zealand. Over the course of its existence, however, NZOC has undergone a number of name changes to reflect the authority and remit of the organisation, and, its associations with various British Empire sporting competitions. Today, the organisation still retains its title as the New Zealand Olympic Committee and reference initials NZOC. See Kohe, At the heart of sport for a chronology of these changes.

${ }^{2}$ Although formally established on 18 October 1911, the effective cessation of most national and international Olympic business during World War One meant that the IOC did not officially get around to recognising NZOC, and accepting its important separation from the Australasian union, until 1919. Nevertheless, three New Zealand athletes had competed as part of an Australasian team at the 1908 Olympic Games (in which Harry Kerr become the country's first Olympic medallist winning bronze in the 3500 metre walk). Three New Zealanders competed again for Australasia at the 1912 Olympic Games. One of the members of this latter team was the national, Australasian and Wimbledon tennis champion Anthony Wilding. Between 1907 and 1914 Wilding's athletic success abroad had helped raise the country's sporting profile and reaffirm imperial ties between Britain, New Zealand and Australia. See Kohe, 'The unexceptional'; Palenski and Maddaford, The Games; Palenski and Romanos, Champions; Romanos, Our Olympic Century and New Zealand's top 100 sports history makers; and Richardson and Richardson, Anthony Wilding for further details.

${ }^{3}$ Such exchanges, of course, not only involved amateur athletics, but other sports, including rugby union and league, and cricket. See, Palenski, The making of New Zealanders; Ryan, The making of New Zealand cricket; Tackling rugby myths; and, 'Sport in $19^{\text {th }}$-Century Aotearoa/New Zealand.

${ }^{4}$ Ibid.

${ }^{5}$ New Zealand Amateur Athletics Association (NZAAA) 1914, 43.

${ }^{6}$ NZAAA, November 23, 1914, 50.

${ }^{7}$ Ibid.

${ }^{8}$ Richardson and Richardson's work, Anthony Wilding: A sporting life, on the multi-Wimbledon Champion Anthony Wilding (who incidentally was killed at the battle of Ypres) provides a particularly good overview of the context and consequences for the nation's athletes during this period.

${ }^{9}$ NZOC, and its allied association the New Zealand Amateur Athletics Association (NZAAA), for example, maintained an active calendar of sport events throughout the country, and, in particular, were diligent in demonstrating support for Australian and American (and occasional British) allies by fostering sporting competition and participating in military athletic championships within the country. NZOC, Official minute book, 1912-1932.

${ }^{10}$ This was largely due to Chairman Arthur Marryatt maintaining correspondence with Australian IOC member and amateur athletic administrator Richard Coombes, and, IOC members in Britain and Europe during the War. Support for the war was also a good public advertisement for NZOC in particular as their official minutes were regularly published in mainstream press.

${ }^{11}$ For example, although NZOC and the NZAAA had made some changes to amateur sport policies (e.g., there were exemptions for physical education teachers, coaches, and blue-collar business sport teams). 
${ }^{12}$ Notwithstanding Grant's assessment, it need be recognised that at the time the country's financial sector was comparably weaker than other areas of the country's economy. However, eventually, as a consequence of countries shifting investments to the Britain - one of the only available free-markets - New Zealand's primary export industry revenues (namely in dairy and agriculture) did plummet. Grant, Bulls, bears, and elephants, 138; Belich, Paradise reforged; Molloy, 'Citizenship, Property and Bodies'. See also Eric Olssen's (1995) 'Towards a new society' for a cogent analysis of the Depression and its consequences for the (re)shaping of New Zealand's social, economic and political landscape.

${ }^{13}$ NZOC, Official minute book, 1912-1932.

${ }^{14}$ NZOC, Communication to the International Olympic Committee.

${ }^{15}$ NZOC, Personal communication Baillet-Latour. Wellington: NZOC, 1934, 19 February.

${ }^{16}$ NZOC, Official minute book, 1912-1932.

${ }^{17}$ NZOC, Official minute book, 1912-1932.

${ }^{18}$ To summarise, Marryatt was initially replaced local educationalist Joseph Firth (tenure 1923-1927), then respected military hero Bernard Freyberg (tenure 1928-1930), and latter, lawyer and expatriate, Cecil Wray (tenure 1931-1934). Despite possibly the best intentions of assisting NZOC with some of the tyrannies of distance it faced, and maintaining the visible profile of New Zealand in transnational sporting discussions, all three of these appointments were ineffectual.

${ }^{19}$ Amos, Personal Correspondence to Freyberg, 22 March, 1930.

${ }^{20}$ Amos, Personal Correspondence to Freyberg, 6 April, 1930. NZOC also exchanged similar dialogue with fellow IOC members Joseph Firth and Cecil Wray. Additionally, and perhaps recognising the benefits of soliciting expatriates, Amos and his colleagues had initially viewed Wray as "a very suitable man" who "would do full justice to the position" (NZOC, Official minute book, 1912-1932, 30 August, 1930, 164).Yet, Wray lasted just three years; during which time his influence on the IOC and NZOC was negligible.

${ }^{21}$ Previously the role had been taken up by associated in Australian and/or Britain, or coaches and chaperones. NZOC, Official minute book, 1912-1932. As was customary at the time, Amos' wife's role was to serve as chaperone to the team's female member.

${ }^{22}$ Ibid, June 26, 1929, 154.

${ }^{23}$ The organisation’s balance at the time was approximately £1245. As such, Amos also worked hard to ensure NZOC's meagre economic resources remained financial stable. Such stability was vital not only the continued participation of New Zealand athletes abroad, but, necessary to demonstrate the organisation's professional capabilities. NZOC, Official minute book, 1912-1932. Wellington: NZOC, 26 June, 1929, 154.

${ }^{24}$ NZOC, Official minute book, 1912-1932; NZOC. Official minute book. 1933-1964

${ }^{25}$ As a reflection of his tireless work for the organisation in 1952 the IOC awarded Amos a prestigious Olympic diploma in recognition for both his administrative nous and enduring support for amateurism.

http://library.la84.org/OlympicInformationCenter/OlympicReview/1952/BDCE34/BDCE34d.pdf, accessed 19 September, 2014.

${ }^{26}$ At the time, Porritt was only the second New Zealand Rhodes recipient.

${ }^{27}$ Porritt went on to repeat this role at the 1928 and 1936 Olympic Games and 1934 British Empire Games.

${ }^{28}$ Amos, personal correspondence to IOC President Comte Henri de Baillet-Latour.

${ }^{29}$ The significance of works such as these is discussed in the latter sections of this paper.

${ }^{30}$ NZOC. Official minute book. 1933-1964.

${ }^{31}$ Ingram, 'Panorama of the playground', 55.

${ }^{32}$ Ibid.

${ }^{33}$ Ingram, 'Panorama of the playground', 54.

${ }^{34}$ See Daley's (2012) piece 'Taking off the Black Singlet' for an insightful discussion of the complicated cultural nuances and historical significance of one of these icons and a broader critique of the construction of the national imagination.

${ }^{35}$ NZOC. Official minute book. 1933-1964, 3 October 1936, 168.

${ }^{36}$ NZOC, Official minute book, 1912-1932

${ }^{37}$ For some of the most interesting examples see Ballantyne's Webs of Empire; Belich, Replenishing the earth; Burton, After the imperial turn'; Gibbons, 'The Far Side of the Search for Identity'; Lambert and Lester, Colonial lives across the British Empire; and, Thompson and Fedorowich's, Empire, Identity and Migration in the British World. In important contradistinction, however, are resistant stances to the paradigm shift that have been variously offered by respected New Zealand scholars such Miles Fairburn (1989) and the late Peter Munz (1971, 1984). To this can be added Niall Fergusson's (2008) broader sweeping and controversial neo-colonial work Empire: How Britain made the modern world that holds fast to the central authority of Imperial forces within transnational and global historiography. 
${ }^{38}$ Ibid. However, Beilharz and Cox provide useful assessments of assumptions about settler capitalism in antipodean colonies, and, the need to be critical of some of the characteristics of the dialectical relationship between New Zealand and its coloniser.

${ }^{39}$ Palenski's The making of New Zealanders offers further examination of the ways in which aspects of this identity were forged in other sporting, and non-sport, contexts. For extended discussion see the range of perspectives and debates presented in Giselle Byrnes' (2009) edited The New Oxford History of New Zealand. Byrnes' introduction and several other chapters therein attend to the argument that the country's historiographical trends need to better consider post-national approaches. The point has been articulated further within the sport context by Malcolm Maclean (2010) in his piece on sport history/historiography in New Zealand. In keeping with the desire to rethink the country's position within Imperial scholarship, Maclean asserts that in a quest for meaning and legitimacy New Zealand sport and its histories have been concomitantly inwardly and outwardly looking.

${ }^{40}$ Consider, for example, traditional allegiance/alliances, and, positioning and politicizing the country's Commonwealth and sporting identities externally and internally.

${ }^{41}$ With the onset of the Empire Games in 1930, and the consequential administrative restructuring of NZOC, Amos' work in redefining the organisations working relationships with its colonial forebears and partners would become even more valuable.

\section{References:}

Amos, Harry. Personal Correspondence to Freyberg (22 March, 1930). Lausanne, IOC files.

Amos, Harry. Personal Correspondence to Freyberg (6 April, 1930). Lausanne, IOC files.

Amos, Harry. Personal correspondence to IOC President Comte Henri de Baillet-Latour (19 February, 1934). Lausanne, IOC files.

Ballantyne, Tony. 2012. Webs of Empire: Locating New Zealand's Colonial Past. Vancouver: University of British Columbia Press.

Beilharz, Peter and Lloyd Cox. 2007 'Settler capitalism revisited'. Thesis Eleven 88: 112-124.

Belich, James. 2001. Paradise Reforged: A history of the New Zealanders from the 1880s to the year 2000. Auckland: Allen Lane.

Belich, James. 2007. Making Peoples: A history of the New Zealanders from Polynesian settlement to the end of the nineteenth century. Auckland: The Penguin Group,

Belich, James. 2009. Replenishing the Earth: the Settler Revolution and the Rise of the Anglo-World, 1783-1939. Oxford: Oxford University Press.

Burton, Antoinette. ed. 2003. After the imperial turn: Thinking with and through the nation. Durham, NC: Duke University Press.

Byrnes, Giselle. ed. 2009. The New Oxford History of New Zealand. South Melbourne: Oxford University Press. 
Colquhoun, David. 2008. As if running on air: The journals of Jack Lovelock. Nelson: Craig Potton Publishing.

Coombes, Annie E. 2006. Rethinking settler colonialism: History and memory in Australia, Canada, Aotearoa New Zealand and South Africa. Manchester: Manchester University Press.

Daley, Caroline. 2012. 'Taking off the Black Singlet'. New Zealand Journal of History 46 (2): 113-128.

Fairburn, Miles. 1989. The ideal society and its enemies: The foundations of modern New Zealand Society, 1950-1900. Auckland: Auckland University Press.

Fergusson, Niall. 2008. Empire: How Britain made the modern world. London: Penguin Books

Gibbons, Peter. 2003. 'The Far Side of the Search for Identity'. The New Zealand Journal of History 37 (1): 38-49.

Grant, David. 1997. Bulls, bears, and elephants: A history of the New Zealand Stock Exchange. Wellington: Victoria University Press.

Henniker, Gary and Ian Jobling. 1989. 'Richard Coombes and the Olympic Movement in Australia: Imperialism and nationalism in action’. Sporting Traditions 6 (2): 2- 15.

Ingram, W.F. 1937. 'Panorama of the playground: Physical fitness and the Daily Dozen', New Zealand Railways Magazine 11 (10): 54-55.

Jobling, Ian. 2000. 'In pursuit of status, respectability and idealism: Pioneers of the Olympic movement in Australasia’. International Journal for the History of Sport 21 (4): 142163.

Kebric, Robert B. 2014. 'London 2012, Chariots of Fire resurrected and Colombes Stadium today: Hype, history and Olympic realities’. Sport in Society 17 (5): 656-673.

Keys, Barbara. 2006. Globalizing sport: National rivalry and international community in the 1930s. Cambridge: Harvard University Press.

King, Michael. 2003. The Penguin History of New Zealand. Auckland: Penguin Books.

Kohe, Geoffery Z. 2010. 'The unexceptional: New Zealand's very ordinary olympic history'. Sport History Review 14 (2): 146-163.

Kohe, Geoffery Z. 2011. At the heart of sport: The New Zealand Olympic Committee and the History of the Olympic Movement in New Zealand. Wellington: NZOC.

Kohe, Geoffery Z. 2012. 'Reflexivity in the apologetic aeon: NZOC’s return to Moscow'. Museum \& Society 10 (2): 121-140. 
Krüger, Arnd and William J. Murray. 2003. The Nazi Olympics: Sport, politics and appeasement in the 1930s. Urbana: University of Illinois Press.

Lambert, David and Alan Lester, eds. 2006. Colonial lives across the British Empire: Imperial careering in the long nineteenth century. Cambridge, UK: Cambridge University Press.

Letters, Michael and Ian Jobling. 1996. 'Forgotten Links: Leonard Cuff and the Olympic Movement in Australia, 1894-1905’. Olympika: International Journal of Olympic Studies 5: 91-110.

Little, Charles and Cashman, Richard. 2001. 'Ambiguous and overlapping identities: Australasia at the Olympic Games, 1896-1914', In Sport, federation, nation, eds. Richard, Cashman, John O‘Hara and Andrew Honey, 81-96. Sydney: Walla Walla Press.

McNeish, James. 1986. Lovelock: A novel. Auckland: Hodder \& Stoughton.

McNeish, James. 1999. 'Death of a dream: The fact and fictions of Jack Lovelock'. In Sport, society and culture in New Zealand, ed. Brad Patterson, 31-37. Wellington: Stout Research Centre.

MacLean, Malcolm. 2010. 'New Zealand (Aotearoa)', In Routledge Companion to Sports History, eds. Pope, Steve W. and John Nauright, 510-25. London: Routledge.

Mangan, James A. and Colin Hickey. 2000. 'Pioneer of the proleteriat: Herbert Milnes and the games cult in New Zealand', In Sport in Australasian society eds. James A. Mangan and John Nauright, 31-48. London: Frank Cass.

Molloy, Maureen. 2007. 'Citizenship, Property and Bodies: Discourses on Gender and the Inter-War Labour Government in New Zealand’. Gender \& History 4 (3): 293-30

Munz, Peter. 1984. 'The two worlds of Anne Salmond in Postmodern fancy-dress'. New Zealand Journal of History 28: 60-75.

Munz, Peter. 1971. 'The Purity of the Historical Method'. New Zealand Journal of History 5: $1-18$.

New Zealand Amateur Athletics Association. Official Minutes (Vol. 2). (11 September, 1914, 42). Wellington: NZAAA.

New Zealand Amateur Athletics Association. Official Minutes (Vol. 2). (23 November, 1914, 50) Wellington: NZAAA.

New Zealand Olympic Committee. Official minute book, 1912-1932. Wellington: NZOC, 26 June, 1929, 154. 
New Zealand Olympic Committee. Official minute book, 1912-1932. Wellington: NZOC, 1912-1932.

New Zealand Olympic Committee. Communication to the International Olympic Committee. Lausanne. 1931, 13 July.

New Zealand Olympic Committee. Official minute book. Wellington: NZOC, 1933-1964.

New Zealand Olympic Committee. Official minute book. 1933-1964, Wellington: NZOC, 1933-1964.

New Zealand Olympic Committee. Official minute book. 1933-1964, Wellington: NZOC, 1933-1964, 3 October 1936, 168.

New Zealand Olympic Commitee, Personal communication Baillet-Latour. Wellington: NZOC, 1934, 19 February.

Olssen, Eric. 1995. 'Towards a new society’, In The Oxford History of New Zealand, Geoffrey Rice, ed, $2^{\text {nd }}$ ed, 254-284. Auckland: Oxford University Press.

Palenski, Ron. The making of New Zealanders. 2012. Auckland: Auckland University Press.

Palenski, Ron and Terry Maddaford. 1983. The Games. Auckland: Moa Publications.

Palenski, Ron and Joseph Romanos. 2000. Champions: New Zealand sports greats of the $20^{\text {th }}$ century. Auckland: Hodder Moa Beckett.

Phillips, John O. C. 1984. 'Rugby, war and the mythology of the New Zealand male'. The New Zealand Journal of History 18 (1): 83-103.

Phillips, John O. C. 1987. A Man's Country: The Image of the Pakeha Male. Auckland: Penguin Books.

Phillips, John O. C. 1990. 'Of Verandahs and Fish and Chips and Footie on Saturday Afternoon: Reflections of 100 years of New Zealand Historiography'. The New Zealand Journal of History 24 (2): 118-134.

Pickles, Katie. 2009. 'Transnational intentions and cultural cringe: History beyond National boundaries'. In Contesting Clio's Craft: New Directions and Debates in Canadian History, ed. Christopher Dummitt and Michael Dawson, 141-61. London: Institute for the Study of the Americas.

Pickles, Katie. 2011. 'The obvious and the awkward: Postcolonialism and the British World'. The New Zealand Journal of History 45 (1): 85-101.

Pocock, John G.A. 1974. 'British History: The Plea for a New Subject'. The New Zealand Journal of History 8 (11): 3-21. 
Richardson, Len and Shelley Richardson. 2005. Anthony Wilding: A sporting life. Christchurch: University of Canterbury Press.

Roche, Michael. 2002. 'Soldier settlement in New Zealand after World War 1: Two case studies’. New Zealand Geographer 58 (1): 23-32.

Romanos, Joseph. 2006. New Zealand's top 100 sports history-makers. Wellington: Trio Books.

Romanos, Joseph. 2008. Our Olympic century. Wellington: Trio Books.

Ryan, Greg. 2004. The making of New Zealand cricket, 1832-1914. London: Frank Cass.

Ryan, Greg. 2005. Tackling rugby myths: rugby and New Zealand society 1854-2004. Dunedin: University of Otago Press.

Ryan, Greg. 2007. 'Sport in 19th-Century Aotearoa/New Zealand: Opportunities and Constraints'. In Sport in Aotearoa/New Zealand Society, ed. Chris Collins and Steve Jackson, 96-111. Auckland: Thomson.

Sinclair, Keith. 1984. A History of New Zealand. Auckland: Penguin Books.

Sinclair, Keith. 1986. A destiny apart: New Zealand's search for national identity. Wellington: Allen \& Unwin.

Sinclair, Keith and Raewyn Dalziel, R, eds. 2000. A history of New Zealand (Revised ed.). Auckland: Penguin Books.

Thompson, Andrew S. and Kent Fedorowich, eds. 2013. Empire, Identity and Migration in the British World. Manchester: Manchester University Press.

Woodfield, Graeme. 2007. Lovelock: Athlete and Doctor. Wellington: Trio Books.

Woodfield, Graeme and Joseph Romanos. 2008. No Ordinary Man: The Remarkable Life of Sir Arthur Porritt. Wellington: Trio Publishers. 